JEP | Volume 5 | Nomor 2| November 2021

e-ISSN 2579-860X

p-ISSN 2614-1221

Doi: https://doi.org/10.24036/jep/vol5-iss2/609

\title{
Pengembangan Media Interaktif Mata Kuliah Teknik Analisis Biologi Molekuler
}

(TABM)

\author{
Fitria Lestari ${ }^{1)}$ \\ ${ }^{1)}$ Program Studi Pendidikan Biologi, Jurusan Pendidikan Matematika dan IPA, STKIP PGRI \\ Lubuklinggau \\ Email: Fitrinq@gmail.com
}

\begin{abstract}
Molecular Biology Analisis Techniques (TABM) is one of the courses that discusses the basic techniques needed for molecular biology. Learning in TABM, is more emphasis on procedural, so the process by using books alone is not enough. Therefore, to support the TABM learning process, interactive were developed consisting of text, sound, images, and research videos. This type of research is $R \& D$ is a research and development design by modifying the systematics of Kemp and Dayton. The development steps are to determine the specific learning objectives of the product; prepare material and video content; creating storyboard, developing, editing, and mxing; testing and revising. The instruments used are validation sheets and questionnaires for students with qualitative and quantitative data analysis techniques. Based on the result, there are several suggestions and inputs including: design, instructions for use, product packaging, introduction of tools and initial materials, and procedures. While quantitatively it can be seen that the developed interactive media doesn't need to be revised and is suitable for use, namely 92,1\% of field experts and 70,2\% of media experts. It can be concluded that the development of interactive media can be used ini procedural courses such as molecular biological analysis techniques.
\end{abstract}

Keywords : Interactive media, Molecular Biology Analysis Techniques (TABM)

This is an open access article distributed under the Creative Commons 4.0 Attribution License, which permits unrestricted use, distribution, and

reproduction in any medium, provided the original work is properly cited. $\bigcirc 2021$ by author.

\section{PENDAHULUAN}

Salah satu mata kuliah yang menuntut mahasiswa untuk menggunakan metode mole kuler yaitu Teknik Analisis Biologi Molekuler (TABM). TABM merupakan metode analisis genetik berdasarkan perubahan komposisi dan fungsi gen. Materi dari mata kuliah TABM ini menjelaskan metode analisis dasar dalam biologi molekuler, meliputi isolasi DNA, elektroforesis agarosa, PCR, dan elektroforesis poliakrilamid. Prosedur analisis biologi molekuler digunakan untuk analisis filogenetik seperti ekstraksi DNA, elektro foresis, PCR, dan sekuensing DNA (Sukoco, dkk., 2016). Analisis molekuler diperlu kan untuk mempermudah memahami berbagai mekanisme molekuler termasuk identifikasi gen, ekpresi, dan ekplorasi protein atau enzim sehingga fungsi gen dan protein dapat diketahui (Fatchiya, dkk., 2011). Harapan setelah meng ikuti pembelajaran mengenai TABM ini, maha siswa akan memiliki pengetahuan dasar tentang teknik-teknik yang digunakan dalam analisis biologi molekuler.

Materi-materi dalam TABM memiliki karakteristik yaitu mengandung prinsip, konsep, dan pembahasannya lebih bersifat prosedural atau teknis dalam melakukan analisis biologi molekuler. Pembelajaran menggunakan buku cetak atau modul tentu saja belum optimal karena buku cetak atau modul hanya menyajikan prosedur-prosedur yang bersifat tertulis dan abstrak dalam melakukan analisis biologi molekuler dan belum menggambarkan teknis analisis biologi molekuler secara nyata. Hal ini mengakibatkan mahasiswa akan mengalami kesu litan mempelajari sebuah proses dari teknik anali sis biologi molekuler. Hal ini tentunya akan menu runkan motivasi dan daya tarik siswa untuk belajar.

Ilmu pengetahuan dan teknologi yang semakin melaju di abad 21 telah menyebabkan besarnya konsekuensi yang berbeda dari sebelum nya (Nahdi, 2019). Abad 21 ini ditandai dengan karakteristik dunia ilmu pengetahuan yang saling bertaut. Semakin menyempit dan meleburnya ruang dan waktu menjadi aspek yang menentu kan percepatan dan keberhasilan ilmu pengetahu an oleh umat manusia. Berbagai jenis teknologi pendidikan dan media digital dapat mendorong siswa untuk meningkatkan kemampuan belajar 
dan peluang pendidikan yang lebih baik (Masykur, 2017).

Keterbatasan pembelajaran TABM perlu diatasi melalui media interaktif. Pembelajaran interaktif ini adalah pembelajaran yang memung kinkan peserta didik untuk membawa objek dan proses yang kompleks, abstrak, teknis ke dalam kelas sehingga menarik, mudah dipahami, dan tidak membosankan. Hal ini disebabkan pada saat mempelajari metode analisis biologi molekuler, pendidikan diberikan dalam bentuk multimedia (terdiri dari teks, suara, gambar, dan video) yang secara jelas menggambarkan materi atau konten. National Education Association of America mendefinisi kan media sebagai segala sesuatu yang dapat dimanipulasi, dilihat, didengar, dibaca, atau didiskusikan dengan alat bantu yang digunakan dalam kegiatan ini (Krisnanto, 2010).

Menurut Handoyo dan Suharto (2003), media interaktif adalah penyajian informasi secara simultan berupa teks, gambar, dan suara sehingga pembelajaran menjadi efektif dan efisien. Penggunaan media interaktif dalam kegiatan pendidikan yang sesuai dengan kemaju an ilmu pengetahuan dan teknologi. Media interaktif dapat digunakan sebagai wahana proses pembelajaran (Qosyim dan Ferit, 2017).

Media interaktif ini sendiri memliki banyak keunggulan, antara lain kemampuannya dalam melayani siswa dalam berbagai gaya belajar. Gaya belajar yang berbeda menuntut peserta didik untuk mengasimilasi materi yang disajikan oleh guru dengan cara yang berbeda. Dengan alasan ini, media merupakan salah satu sarana belajar yang oprimal karena kebutuhan siswa akan suatu materi tertentu berbeda dengan yang lain (Arsyad, 2011). Hal ini didukung oleh Mulyana dan Leong (2009) yang berpendapat bahwa pembelajaran akan optimal jika alat peraga yang disajikan sesuai dengan karakteris tik gaya belajar peserta didik. Pembelajaran menggunakan media interaktif cocok digunakan sebagai lingkungan belajar yang mendkung pemahaman materi (Arda, dkk., 2015).

Berdasarkan permasalahan yang telah dike mukakan, peneliti tertarik untuk melakukan penelitian yang bertujuan untuk mengembang kan media interaktif sebagai bagian dari mata kuliah "Teknik Analisis Biologi Molekuler"

\section{METODE PENELITIAN}

\section{Model Penelitian dan Pengembangan}

Menurut Sukmadinata (2007) penelitian dan pengembangan $(R \& D)$ adalah proses atau langkah mengembangkan produk baru yang dapat dibayangkan atau meningkatkan produk yang sudah ada. Dalam penelitian ini, media interaktif dikembangkan dengan menggunakan model Kemp dan Dayton (1985).

\section{Prosedur R\&D}

Prosedur R\&D berikut ini konsisten dengan fase desain medi ainteraktif komputer yang dimodifikasi dengan model Kemp dan Dayton (1985). Langkah-langkah yang dilaku kan sehubungan dengan model pengembangan yang digunakan adalah:

a. Tentukan tujuan tertentu (goal) untuk pelatihan produk

Tujuan pembelajaran adalah arah dan tujuan akhir kompetensi yang ingin dicapai dalam proses pembelajaran, dan berfungsi sebagai pedoman atau pedoman bagi peserta didik untuk mencapainya. Adapun tujuan khusus pembelajaran TABM ini adalah:

1) Menjelaskan konsep dasar ekstraksi DNA

2) Menjelasakan konsep dasar elektroforesis agarosa

3) Menjelaskan konsep dasar elektroforesis poliakrilamida

4) Menjelaskan konsep dasar Polymerase Chain Reaction (PCR)

5) Mahasiswa dapat menyebutkan prosedur kerja isolasi DNA

6) Mahasiswa dapat menyebutkan prosedur kerja elektroforesis agarose

7) Merujuk ke prosedur operasi sebagai Polymerase Chain Reaction (PCR)

8) Menjelaskan konsep dasar elektroforesis poliakrilamida prosedur dari ekstraksi DNA

b. Penyusunan Materi Ajar dan Konten Video (Content Diagram)

Merupakan bentuk penyusunan butir materi berdasarkan rumusan tujuan pembelajar an tertentu. Materi yang ditampilkan pada media interaktif adalah pemisahan DNA, elektroforesis gel agarosa, OCR, dan elektroforesis gel poliakri lamida. Masing-masing sumber media interaktif ini memuara konsep dasar, alat, dan sumber daya. Keselamatan kerja, prosedur kerja, dan temuan laboratorium untuk mengidentifikasi variasi genetik kerbau lokal (Bubalus bubalis) lokal, video, diskusi, dan laporan.

c. Membuat Storyboard 
Langkah selanjutnya dalam Kemp dan Dayton (1985) adalah membuat storyboard yang berbentuk sketra dengan catatan tentang isi cerita.

\section{d. Pengembangan, Pengeditan, dan}

Pencampuran

Setelah pengembangan, pengeditan, dan pencampuran storyboar selesai. Langkah selanjut nya adalah membuat media pembelajaran interak tif. Model produksi Kemp dan Dayton (1985) dikenal sebagai development, editing, dan mixing. Dalam proses ini, developer menyiapkan semua materi dalam format teks, audio, gambar, dan video dan menggabungkannya dengan prog ram Adobe Flash Player untuk mendapatkan media yang diinginkan. Hasil pengembangan dikemas dalam bentuk $\mathrm{CD}$.

\section{e. Pengujian dan Revisi}

Tahap pengujian dan revisi membantu menguji kelayakan suatu produk namun pene litian ini terbatas pada penelitian, media, dan uji lapangan. Dalam fase pengujian dan revisi ini, kami menggunakan lembar validasi dan survei untuk mengumpulkan data terkait produk dan menggunakan data yang diambil sebagai refe rensi untuk revisi atau perbaikan produk.

\section{Pengujian produk}

Tujuan pengujian produk adalah menda patkan data yang mendasari untuk melakukan perbaikan untuk mencapai tingkat kecukupan.

\section{a. Desain Pengujian Produk}

Pada dasarnya, kegiatan pengujian produk pengembangan dilaksanakan sebagai langkah evaluasi formatif, yang terdiri atas uji coba ahli bidang studi, uji coba ahli media pembelajaran, dan uji coba kelompok kecil.

b. Subjek Uji Coba Produk

1) Validasi Ahli Bidang Pelajaran

Penetapan ahli bidang pelajaran didasar kan pada dua pertimbangan. Pertama, memiliki latar belakang akademis di bidang genetika dan biologi molekuler. Kedua, menguasai materi yang berkaitan dengan TABM.

2) Validasi Ahli Media Pembelajaran

Keputusan sebagai ahli media pembela jaran didasarkan pada kriteria sebagai berikut: pertama, pendidikan Magister (S2) atau Doktor (S3) sebelumnya di bidang Teknologi Pembe lajaran. Kedua, memiliki keahlian di berbagai lembaga pendidikan. Studi desain pembelajaran.

\section{3) Studi Kelompok Kecil (Mahasiswa)}

Tujuan dari penelitian ini adalah untuk mengetahui kualitas media interaktif mengguna kan mikrosatelit untuk mengidentifikasi variasi genetik kerbau lokal Sumatera Selatan (Bubalus bubalis).

\section{c. Jenis Data}

Data yang diperleh dari hasil pengujian produk pengembangan media interaktif adalah data deskriptif kualitatif dan deskriptif kuantitatif yang digunakan untuk meningkatkan hasil pengembangan produk. Data kualitatif berupa tanggapan dan saran perbaikan dari penguji produk (ahli bidang penelitian dan pakar media pembelajaran). Data kuantitatif diperoleh dari hasil verifikasi kedua ahli dan kuesioner dibagikan kepada subjek dalam kelompok kecil.

\section{d. Alat Pengumpulan Data}

Alat pengumpulan data berikut diguna kan untuk mendapatkan jumlah data yang diharap kan.

1) Lembar Validasi

Lembar validasi digunakan untuk mengum pulkan data dari hasil uji validator. Lembar validasi diberikan kepada validator untuk diberi skor dengan mencentang $(\sqrt{ })$ setiap aspek yang dievaluasi pada daftar yang tersedia.

\section{2) Kuesioner}

Kuesioner merupakan suatu metode pengumpulan data dengan mengajukan pertanya an-pertanyaan yang dijawab dengan tujuan survei guna memperoeh informasi dari para ahli. Survei studi kelompok kecil (mahasiswa) dirancang untuk memberikan umpan balik tentang desain produk.

\section{e. Teknik Analisis Data}

Ada dua teknik analisis data yang diguna kan untuk mengolah data hasil telaah pakar: analisis deskriptif kualitatif dan kuantitatif.

\section{1) Analisis deksriptif kualitatif}

Analisis deskriptif kualitatif telah diguna kan untuk mengolah data dari laporan ahli. Teknik analisis data ini digunakan dengan mengelompokkan informasi dari data kualitatif berupa jawaban dan saran perbaikan dari validasi ahli bidang dan validasi ahli media pembelajaran. Analisis data menjadi acuan untuk menyempur nakan atau merevisi produk pengembangan media interaktif ini. 
2) Analisis statistik deskriptif kuantitatif

Analisis statistik deskriptif kuantitatif digunakan untuk menganalisis data yang dikum pulkan dari survei. Data survei dianalisis untuk mendapatkan gambaran yang utuh tentang media pembelajaran yang dikembangkan. Setelah kui sioner terkumpul, maka persentase setiap item pertanyaan dalam kuesioner dihitung dengan menggunakan rumus yang digunakan, yaitu rumus yang mengolah persentase tiap item:

$$
\mathrm{P}=\frac{x}{x_{i}} \times 100 \%
$$

Rumus yang mengolah total data

$$
\mathrm{P}=\frac{\sum X}{\sum x_{i}} x 100 \%
$$

Keterangan:

$\mathrm{P}=$ Persentase

$\mathrm{x}=$ Jumah skor jawaban responden dalam satu item

$\mathrm{xi}=$ Jumlah skor ideal dalam satu item

$\sum \mathrm{x}=$ Total jumlah skor jawaban reponden

$\sum \mathrm{xi}=$ Total jumlah skor ideal

$100=$ Konstanta

Pemberian makna dan pengambilan keputusan tentang kualitas produk media interaktif ini, dirujuk sesuai dengan Tabel 1 tentang kriteria tingkat validitas, yaitu.

Tabel 1. Pengambilan Keputusan Revisi Media Interaktif

\begin{tabular}{ccc}
\hline $\begin{array}{c}\text { Tingkat } \\
\text { Pencapaian }\end{array}$ & Kategori & Keputusan Uji \\
\hline $81-100$ & Sangat baik & $\begin{array}{c}\text { Tidak perlu } \\
\text { direvisi } \\
\text { Tidak perlu } \\
\text { direvisi }\end{array}$ \\
$61-80$ & Baik & Direvisi \\
& Cukup & $\begin{array}{c}\text { Direvisi } \\
41-60\end{array}$ \\
$21-40$ & $\begin{array}{c}\text { Kurang baik } \\
\text { Sangat }\end{array}$ & Direvisi \\
& kurang & \\
\hline
\end{tabular}

(Diadaptasi dari Suwastono (2011))

\section{HASIL DAN PEMBAHASAN}

\section{Penyajian Data Tes}

Hasil uji coba media interaktif terdiri dari validasi ahli bidang studi, validasi ahli oleh media pembelajaran, dan hasil uji coba kelompok kecil atau mahasiswa. Data yang diperoleh terdiri dari dua bagian yaitu data deskriptif kualitatif dan kuantitatif. Data deskriptif kualitatif berupa saran dan masukan, sedangkan data deskriptif kuanti tatif berupa evaluasi media interaktif melalui lembar validasi ahli lapangan dan ahli media pembelajaran dan survei mahasiswa dalam skala Likert. Berikut adalah data dari penelitian ahli di bidang penelitian saran dan masukan.

a. Data Hasil Uji Coba Ahli Bidang Studi

Saran dan masukannya sebagai berikut.

1) Video masih banyak sekuel yang tidak fokus karena terlalu banyak gerak, sehingga mem pengaruhi kualitas gambar video.

2) Suara moderator yang memunculkan intonasi dan ketertarikan pengguna.

b. Data Hasil Uji Coba Ahli Media

Pembelajaran

Berikut saran dan masukan hasil pengujian dari ahli media:

1) Desain media, cover, termasuk housing perlu dibuat semenarik mungkin

2) Setiap awal di media itu sendiri, instruksi serta tombolnya tidak jelas

3) Sistem yang berisi tombol harus konsisten

c. Data Survei Mahasiwa

Saran dan masukan dair 10 mahasiswa, dapat dirangkum sebagai berikut:

1) Materi TABM yaitu pemisahan DNA, elektroforesis gel agarosa, PCR, elektro foresis gel poliakrilamida, harus diberikan penjelasan singkat tentang operasi atau pertim bangannya

2) Desain visual perlu lebih menarik, terutama dalam hal warna yang digunakan dalam media.

3) Kita perlu menjelaskan alasan mikrosatelit dan memilih darah sebagai media pengu jiannya.

4) Disarankan agar media interaktif ditingkat kan tidak hanya untuk pelajaran TABM, tetapi juga untuk setiap materi perkuliahan.

5) Alat-alat perlu dipresentasikan terlebih dahulu

6) Membuat paket $\mathrm{CD}$ agar lebih menarik, dna

7) Menjelaskan prosedur kerja secara perlahan agar lebih mudah dipahami

\section{Analisis Data}

Selanjutnya data verifikasi dari ahli media dan ahli bidang pelajaran digunakan untuk menentukan kelayakan aspek desain. Statistik deskriptif kuantitatif digunakan untuk menge tahui aspek kelayakan desain. Hasil analisis data yang dihasilkan kemudian dibandingkan dengan Tabel 1 terhadap kriteria pemilihan media interaktif. 
a. Analisis Nilai Validasi Pakar Bidang Studi

Adapun hasil analisis skor validasi ahli bidang studi, disajikan pada Tabel 2 .

Tabel 2. Skor Validasi Bidang Studi

\begin{tabular}{lll}
\hline Ahli & $\mathbf{P}(\boldsymbol{\%})$ & Keputusan Uji \\
\hline Bidang Studi & 92,1 & Tidak Perlu Revisi \\
\hline
\end{tabular}

Produk media interaktif ini dikategoraikan sangat baik dan tidak perlu direvisi lagi, tetapi perlu ditingkatkan berdasarkan saran dan masuk an dari pakar bidang studi.

b. Analisis Skor Validasi Pakar Media

Pembelajaran

Adapun hasil analisis skor validasi ahli media pembelajaran, disajikan pada Tabel 3.

Tabel 3. Skor Validasi Ahli Media Pembelajaran

\begin{tabular}{llcc}
\hline No & \multicolumn{1}{c}{ Ahli } & $\begin{array}{c}\text { P } \\
(\boldsymbol{\%})\end{array}$ & $\begin{array}{c}\text { Keputusan } \\
\mathbf{U j i}\end{array}$ \\
\hline 1 & Media & 70,2 & Tidak Perlu \\
& Pembelajaran & & Revisi \\
\hline
\end{tabular}

Produk media ini dikategorikan sangat baik dan tidak perlu direvisi lagi, namun perlu ditingkatkan berdasarkan saran dan jawaban dari ahli media pembelajaran.

c. Analisis Hasil Kuesioner Respon Mahasiswa

Adapun analisis skor angket tanggapan 10 mahasiswa, disajikan pada Tabel 4.

Tabel 4. Skor Angket Tanggapan Mahasiswa

\begin{tabular}{lll}
\hline Angket & P(\%) & Keputusan Uji \\
\hline Tanggapan & 84,2 & Tidak Perlu Revisi \\
Mahasiswa & & \\
\hline
\end{tabular}

Hasil analisis data angket tanggapan mahasiswa, diperoleh persentase nilai sebesar 84,2 dan berdasarkan Tabel 1 kriteria kelayakan, maka nilai tersebut termasuk pada kategori sangat baik dan tidak perlu direvisi lagi. Berdasarkan hasil analisis data, khasil perbaikan produk media interaktif tidak perlu diberikan angket kedua.

\section{Revisi Media Interaktif}

Berdasarkan data kualitatif, komponen media interaktif berikut ini perlu diperbaiki, yaitu:

a. Desain visual terutama warna dan tulisan "Teknik Analisis Biologi Molekuler" baiknya dipilih 1 saja.
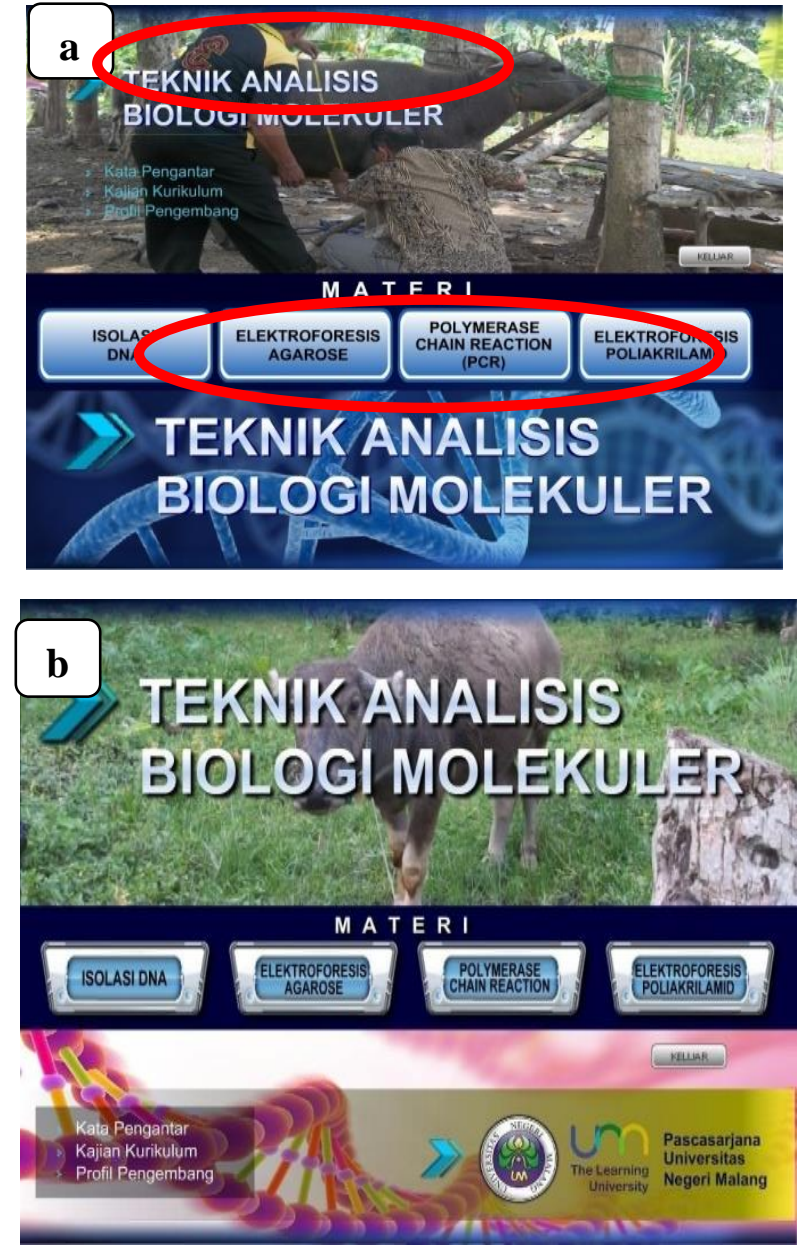

Gambar 1. Tampilan Pembuka Media Interaktif (a. sebelum Direvisi dan b. Setelah Direvisi)

b. Alat-alatnya diperkenalkan terlebih dahulu atau ditampilan gambar atau videonya

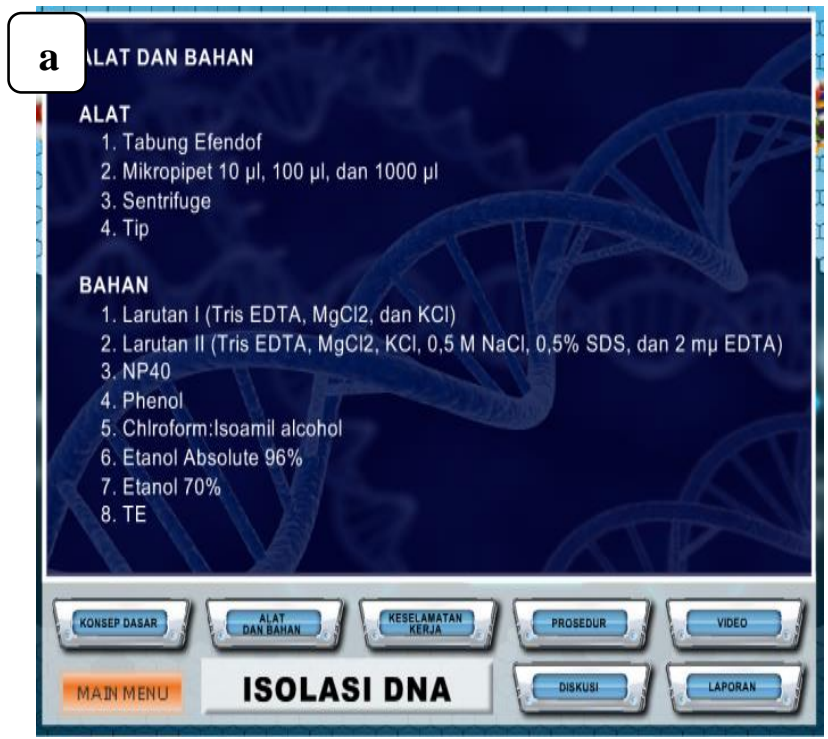




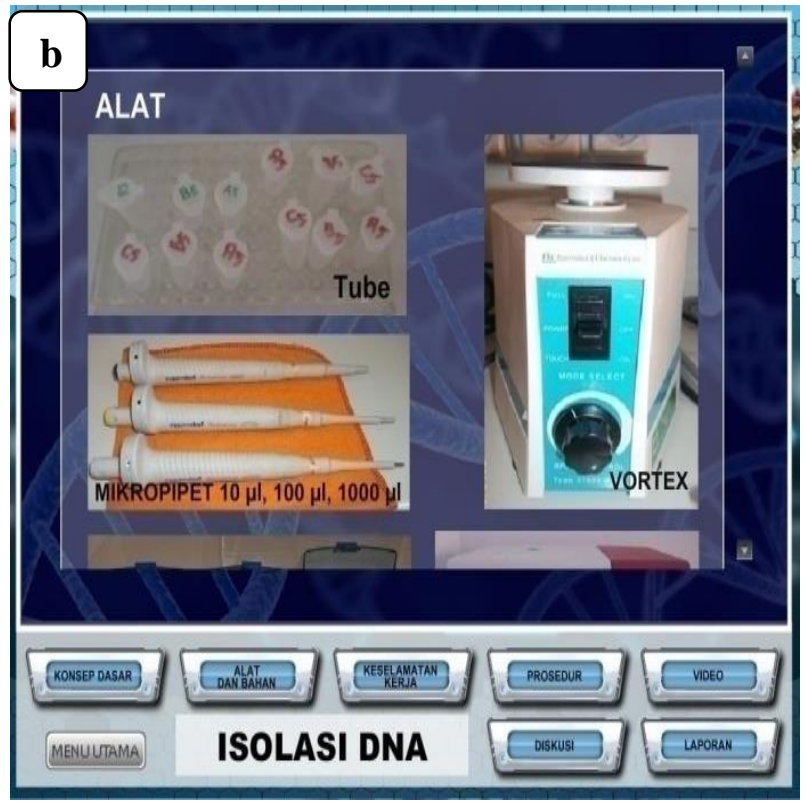

Gambar 2. Tampilan Alat dan Bahan (a. Sebelum Direvisi dan b. Setelah Direvisi)

Penggunaan visual berupa warna, teks, gambar, dan video yang semula tidak menarik. Kemudian digabungkan dengan warna lain dengan nilai yang sama: ungu, kuning, hijau, dan pink. Sadiman, dkk (2009), membantu mencapai tujuan pembelajaran dengan menggabung teks, gambar, audio, musik, fambat animasi, atau video dengan unit yang saling mendukung. Pemilihan warna yang tepat membuat proses belajar menja di lebih menarik (Sudjana dan Rivai, 2009).

Teks yang awalnya berukuran standar 12 , kemudian diubah menjadi ukuran yang lebih besar, yaitu 16. Foto-foto yang awalnya diambil sedikit kemudian dimasukkan kembali ke bagian alat dan bahan. Itu juga terlalu cepat diganti karena awalnya berisi sparepart, yang memper lambat sparepart. Selain itu, audio tidak menarik untuk digunakan pada narasi, musik, dan efek suara. Bagian musik yang semula hanya terdapat pada bagian pertama, ditambah dengan perubahan semua komponen media interaktif. Selanjutnya, ubah efek suara agar tidak jelas.

\section{c. Kemasan}

Kemasan dikemas dalam bentuk CD media interaktif. Produk ini berfungsi sebagai sarana untuk proses pembelajaran TABM di dalam kelas. Produk menampilkan teks, audio, gambar, dan video. Beberapa sumber memerlukan deskripsi detail desain visual berupa warna, teks, gambar, dan video, serta desain audio berupa narasi, musik, dan efek suara. Dosen dan mahasiswa dapat menggunakan $\mathrm{CD}$ media interaktif ini dengan meletakkan di ruang CD komputer atau laptop (Gambar 3). Daryanto (2011) menjelaskan bahwa format presentasi dalam format CD atau DVD memudahkan pengguna untuk menyajikan konten yang dikandungnya. Produk ini juga dapat disimpan ke hard drive atau flashdisk anda.

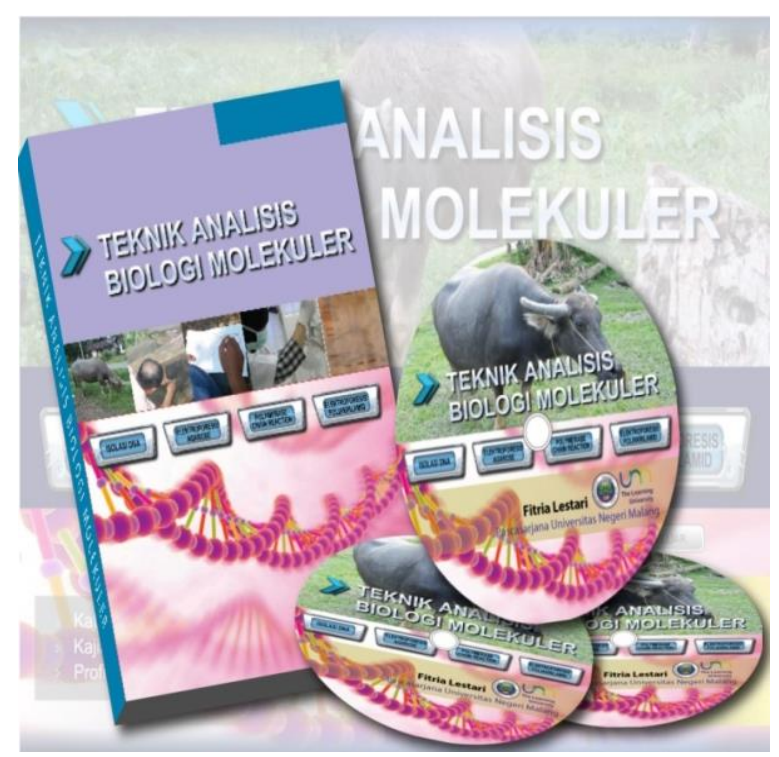

\section{Gambar 3. Kemasan CD Interaktif}

Berdasarkan validasi ahli dan hasil angket respon mahasiswa, kami menemukan bahwa media interaktif yang dikembangkan cocok untuk digunakan pada mata kuliah TABM.

Media interaktif merupakan pilihan yang efektif dibandingkan dengan media lainya. Hal ini didukung oleh Mulyana dan Leong (2009), dimana $65 \%$ informasi dapat diingat oleh audiens ketika informasi disampaikan melalui gambar, tetapi hanya $40 \%$ dengan suara. Penonton mengingat apa yang diinformasikan. Johnson (2006) juga menemukan bahwa pembelajaran kontekstual adalah konteks kehidupan seharihari, yaitu situasi pribadi, sosial, dan budaya. Pembelajaran kontekstual ditandai dengan pembelajaran yang menyenangkan, kolaboratif, bersemangat, penggunaan berbagai sumber, dan pembelajaran terpadu.

Media adalah berbagai jenis komponen lingkungan siswa yang dapat mendorong siswa untuk belajar (Hiedayat dan Sulistiyowati, 2010). Sadiman, dkk (2009) menyarakan beberapa alasan penting untuk menggunakan media untuk pembelajaran, yaitu: 1) memperjelas penyajian pesan agar tidak terlalu verbal (dalam bentuk bahasa tulis atau lisan), 2) mengatasi keterbatas an ruang, waktu, dan indera, dan 3) penggunaan 
media pendidikan yang tepat dan beragam dapat mengatasi kepasifan siswa.

\section{KESIMPULAN}

Berdasarkan hasil penelitian, penggunaan media interaktif pada mata kuliah TABM sangat praktis di lapangan, lebih empiris, dan dapat mempermudah pembelajaran pada fasilitas laboratorium yang terbatas.

\section{DAFTAR PUSTAKA}

Arda., Sahrul, S., Darsikin. (2015). Pengemban gan Media Pembelajaran Interaktif Berbasis Komputer Untuk Siswa SMP Kelas VIII. Jurnal Mitra Sains, 3 (1): 69 77

Arsyad, A. (2011). Media Pembelajaran. Jakarta: Rajawali Pers

Daryanto. (2011). Media Pembelajaran. Bandung: PT. Sarana Tutorial Nurani Sejahtera

Fatchiyah, dkk. (2011). Biologi Molekuler: Prinsip Dasar Analisis. Jakarta: Erlangga

Handoyo, B \& Suharto, Y. (2003). Aplikasi Multimedia untuk Pembelajaran Geografi. Malang: Geo Spektrum Press

Hiedayat, S.W., dan Sulistiyowati. (2010). Pengembangan Komputer Pembelajaran (CAI) tentang Gerak Lurus Berubah Beraturan Pada Mata Pelajaran Fisika Bagi Siswa Kelas VII SMP Negeri 2 Surabaya. Jurnal Teknologi Pendidikan Universitas Negeri Surabaya, 10 (1): 8699

Jhonson B.E. (2006). Contextual Teaching and Learning. Diterjemahkan oleh Ibnu Setiawan. Bandung: MLC

Kemp, J.E., dan Dayton, D.K. (1985). Planning and Producing Instructional Media. New York: Harper \& Row Publisher Inc.

Krisnanto, A. (2010). Pengembangan Media Komputer Pembelajaran Multimedia Mata Pelajaran Fisika Pokok Bahasan Sistem Tata Surya Bagi Siswa Kelas 2 Semester 1 Di SMAN 22 Surabaya. Jurnal Teknologi Pendidikan Univer sitas Negeri Surabaya, 10 (2): 12-25
Masykur, R. (2017). Pengembangan Media Pembelajaran Matematika dengan Macro media Flash. Jurnal Pendidikan Mate matika Al-Jabar, 8 (2): 177-186

Mulyana, St., dan Leong M. (2009). Multimedia Interaktif Media Pembelajaran. Yogya karta: Universitas Atma Jaya

Nahdi, D.S. (2019). Keterampilan Matematika di Abad 21. Jurnal Cakrawal Pendas, 5 (2): 133-140

Qosyim, A., dan Ferit. V.P. (2017). Penerapan Media Pembelajaran Interaktif Menggu nakan Flash Untuk Materi Sistem Gerak Pada Manusia Kelas VIII. Jurnal Penelitian Pendidikan IPA, 2 (2): 38-44.

Sadiman A., Rahardjo R., dan Haryno A. (2009). Media Pendidikan. Jakarta: PT. Raja Grafindo Persada

Sudjana, N., dan Rivai, A. (2009). Media Pengajaran. Bandung: PT. Sinar Baru Algensindo

Sukoco., Amin, M., dan Gofur, A. (2016). Pengembangan Buku Ajar TABM Berbasis Penelitian Untuk Mahasiswa S1 Jurusan Biologi Universitas Negeri Gorontalo. Jurnal Pendidikan: Teori, Penelitian, dan Pengembangan. 1 (6), 1098-1103.

Suwastono. (2011). Pengembangan Pembela jaran E-Learning Berbasis Moodle pada Mata Kuliah Penginderaan Jauh S-1 Jurusan Geografi Universitas Negeri Malang. Tesis tidak diterbitkan. Malang: PPS UM 